\title{
The Role of Consultant Knowledge, Top Management Support, and Operational Manager Competence to the Company Performance
}

\author{
Pirmanta Sebayang ${ }^{1 *}$, Zeplin Jiwa Husada Tarigan ${ }^{2}$, Yessy Peranginangin ${ }^{3}$ \\ ${ }^{1}$ Accounting Courses-University Tama Jagakarsa, Letjen T.B. Simatupang No. 152, \\ Jakarta, 12530, Indonesia. \\ ${ }^{2}$ Department of Management, Faculty of Business and Economics, Petra Christian University, \\ Siwalankerto 121-131, Surabaya 60236, Indonesia. \\ ${ }^{3}$ School of Business Monash University, Logan Selatan 46150, Bandar Sunway, Malaysia
}

\begin{abstract}
Successful implementation of ISO 9000 is determined by the knowledge of the appointed consultants that is demonstrated through their expertise in transferring knowledge to internal companies, the strong willingness of the top management commitment during the implementation, and the capabilities of the operational managers to implement all clauses of ISO to the company through the expertise and experience of managers in the operational section. These three components will perform a collaborative process by doing some organizational learning about quality management to properly implement ISO 9000 in order to have an impact on improving the best business practices in the company's operations and ultimately to improve the company's performance. Based on the results of the survey with questionnaires to a population of 159 companies with two incomplete informants, data processing is performed on 157 manufacturing companies in the area of MM-2100, Cikarang Bekasi, Indonesia. The results of the research analysis with the use of SEM Amos data analysis states that, first of all, the consultant knowledge and the competency of operation manager together can give an increase to the organizational learning. Second, the competency of the operational managers and organizational learning produce the best business practices for the manufacturing companies to improve their corporate performance in the area of MM-2100, .
\end{abstract}

Keywords: Consultant expertise, ISO 9000, manufacturing, organizational learning,

\section{Introduction}

The operation management function in the modern management approach has been integrated with other functions, so it is not complete if the business management functions do not understand the operations management. Nowadays, all profit-oriented organizations

*Corresponding author: firmanta.sebayang@gmail.com 
generally have the function of creating or making a product and doing service business (service industry). Therefore, everyone involved should understand how efficient and effective business processes to add value to their customers [1].

The concept of operations management is proliferating along with the rapid development of the computer. In the early 1990s, IBM came out with their new COPICS software update, which introduced the abbreviation of CIM (Computer Integrated Manufacturing). The newer CIM framework offered a complete strategy to help integrate information consistently and effectively across companies. This framework had three support levels, and the highest level was supporting functional management, which included marketing, factory operations, physical distribution, and business management. This reference occurs to the "whole company," the shift from the initial MRP to MRP II [2]. In the same period, there was an increase in the integrated quality management system with the issuance of ISO (International Organization for Standardization) by 176 expert technical committees from 160 countries in 1987. ISO was issued with the aim that all products issued by manufacturing and service companies had a common standard by considering the value for companies and consumers based on efficiency and effectiveness [3].

Companies that own and use their resources and capabilities efficiently have a greater opportunity to operate more economically and better in satisfying their customers. Heterogeneity implies that a company with multiple capabilities can compete well and can reach its breakeven point as the minimum yield. Companies with marginal resources, however, can only hope to break even. Meanwhile companies with superior resources will gain their competitive advantage as long as they are able to control their resources so that they are not enticed by others or competitors.

The top management of the company, known as the leader, should be able to create an environment that employees and organizations can grow and learn to create new ideas and knowledge. Many academics and consultants may be invited by top management companies to induce learning and sharing knowledge with the employees and other internal corporate departments in order to create the best practices in the company [4]. Sharing knowledge in the company will contribute to the improvement of the company's performance.

Companies can build their competitive advantages through the development and selection of an appropriate technology to the company's conditions [5]. Build the company's competitiveness by considering the technical and institutional strategy to support product development, put into consideration several resources factors, such as capital, raw materials, and employee competences. One of the answers to this question is about the implementation of TQM applied through ISO. The implementation of ISO 9000 can maintain the sustainability of business practices. ISO 9000 as an international standard talk about how an organization can produce a quality output (product or service), which is given to customers or users with consistent quality and continual improvement [6]. ISO 9001: 2008 recognizes that an integrated quality process involving all parts and functions of the organization. Everyone has a role in ensuring quality and plays an important role in realizing customer satisfaction [7].

In the industrial area MM 2100 in Cikarang Bekasi, Indonesia many companies often request the assistance of consultants to improve their productivity and efficiency through specific projects, including ISO, cost accounting, information systems, TQM, production efficiency, and service effectiveness. This research focuses on some companies that have implemented ISO in the industrial area MM-2100 Cikarang Bekasi because the use of ISO consultants is the largest use of consultancy, which comprises $63 \%$ of all companies in the region, with the less expensive cost of implementation but giving a direct impact to the operation managers in company. In reality, the implementation of the ISO, which is 
planned for eight months to $12 \mathrm{mo}$, are often delayed from the schedule, and some even are completed after 36 mo. This is due to the dependence of many project managers to the ISO consultants to improve or revise the documentation and related forms. Based on the discussions with several project managers, the use of project costs always exceeds the planned budget. This is due to the fact that project managers are unable to transfer the knowledge to other department managers so that the mutually agreed project implementation process can be run simultaneously.

\subsection{The problem statements}

Based on the description of the research background above, the formulation of the problems in achieving the operational best practice is as follows:

i. Is the knowledge of ISO consultant capable of improving the learning process of the organization within the company?

ii. Are the operational manager's skills capable of improving the learning process of the organization within the company?

iii. Is the operational manager's expertise, capable of producing the best practices?

iv. Is the improvement of the learning process in the organization capable of generating the discovery of the best practices?

$\mathrm{v}$. Is the improvement of the learning process in the organization able to result in improved corporate performance?

vi. Is the improvement of the best practices resulting in improved corporate performance?

\section{Research concept frameworks}

The increasing global competition requires all companies to be able to build business systems more effectively and efficiently [8]. Creating an effective and efficient communication process requires many companies to share knowledge and learning processes between units within the organization and outside the companies [9]. Sharing knowledge is a process of communication in receiving and sending messages and explaining them to others. Knowledge sharing can be done on an ongoing basis between the company, between members within the company and between different management levels within the company [10].

Many units within the organization states that the perception of management is crucial to the process of sharing knowledge, such as the formal organizational structure within the company, the complexity of the problems confronted the company, and the company's focus for the future. Job specialization is one of the complex factors in sharing knowledge [11]. However, enable to cooperate and communicate effectively and efficiently within the organizational structure determined by the organization's top management as well as the formation of teams from different units require a forum for sharing knowledge within the company. Organizations that are continually trying to build sharing knowledge or referred to as organizations willing to learn from their experiences will be more successful than those that do not share knowledge [12]. In order to maintain and achieve a competitive advantage in a rapidly changing business environment, organizations must be able to improve their learning capacity [13]. An organization learns through a variety of ways, including learning organizations that emphasize the use of learning processes at the individual, group, and organizational levels to transform organizations into different ways to increase satisfaction.

The success indicator in organizational learning process is the broader and more intensive the mechanism of joint learning (organization), because the organization is able to 
make continuous improvement processes by improving the quality of the perspective and the way of thinking, and the organization is able to carry out the social innovation process through improving the quality of its paradigm. The main objective of the organizational learning process is the institutionalization of the collective knowledge of members as a result of integration (sharing knowledge and / or sharing of mental models), which is actualized in the form of organizational strategies, programs, systems, and guidelines.

Many scholars and consultants can be invited by the company's top management to learn and share knowledge with employees and internal corporate departments in order to create best practices in the company [4]. The activity and expertise of consultants who are engaged in making effective and open communication participate in making a more positive influence on knowledge sharing and learning processes in the company. Also, the information provided by consultants through training will have a positive impact while sharing knowledge in South Korea [14].

The utilization of technology in producing best practices through efficiency and effectiveness brings an impact on the company performance, which is measured by the company's financial performance index in Korea [15]. Meanwhile, the best safety of car drivers in the United States is obtained when drivers are wearing seatbelts well, taking into account the safety management system and driving best practices gained through the adoption of ISO 9000 and ultimately providing better financial performance of car manufacturing companies [16].

Many companies in the industrial area of MM-2100 need to implement the ISO to make continuous and consistent improvements that always deliver products to meet customer needs in the global marketplace. The implementation of ISO in the company must go through some stages as follows: first, the need for management to decide which quality management standard to adopt, in this research is ISO 9000:2008. This ISO requires manufacturing companies to make products that meet customer demands with certain specifications. Second, the implementation of ISO requires a strong commitment from the top management level of each organization. Third, the top management level can assign the project team or their trusted people to implement the ISO project; in this case, the operational or related department managers. Fourth, the teams must be able to apply ISO clauses aimed at implementing the ISO system. The implementation of this ISO will produce the best practices for the company because the ISO always sets a detailed procedure on how to implement correctly and effectively for the company. These practices are obtained whenever any improvements are made through findings when audited by external and internal auditors [1].

ISO 9000 will be a requirement for companies that produce manufacturing goods so that they are committed to implementing ISO correctly and adequately in order to perform the appropriate standards and in accordance with the time set. Today many health industries are implementing ISO 900 in order to be customer-oriented, strive for continuous improvement, reduce and prevent nonconformities through standardizing hospital patient handling, comply with environmental regulations, control and reduce environmental impacts, and finally get public recognition. Based on the above explanations, the framework can be described in Figure 1. 


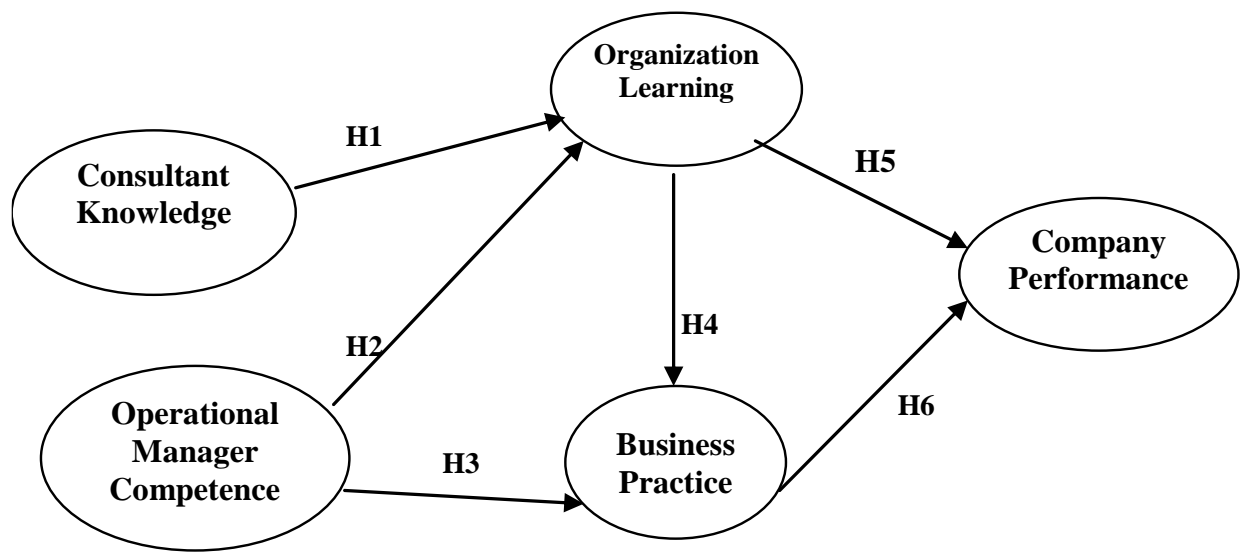

Fig. 1. The research concept framework

Based on the research concept framework, some hypotheses can be obtained as follows:

i. The knowledge of ISO consultants is capable of improving the learning process of organizations

ii. The expertise of operational managers is capable of improving the learning process of organizations within the company.

iii. The expertise of operational managers is able to produce best practices.

iv. The improved organizational learning process is capable of generating the discovery of best practices.

v. The improved organizational learning process is able to produce improvement in company performance.

vi. The improved best practices can result in improved company performance.

\section{Method}

The type of this research is to explain the interrelationships between the variables through hypothesis testing. This study examines the consistency and develops the influence of knowledge sharing to produce best practices for the company toward operational performance and competitiveness. Based on the research formulation, this research is conducting an explanatory research approach, which is meant to explain the position of the studied constructs and the relationship between one construct with another construct. The data sources for this research are taken from companies located in the industrial area MM2100 in Cikarang Bekasi, Indonesia. Companies to be used as samples in this study are manufacturing companies, as many as 250 manufacturing companies. 157 companies have adopted ISO for the management improvement and produced the best operational practices.

A sample is a part of the population or a part of the number and characteristics of the population. As a procedure to determine a portion of the population, a survey sample is taken and used to determine the desired traits of the population. To create a representative sample size, the number of samples in this research is determined as many as 128 companies. To test the first hypothesis up to the last hypothesis and to produce a fit model, the analysis in this research is using Structural Equation Model (SEM) with the calculation process assisted by Amos 16 software application program. The reason for using this model is because there is a tiered relationship structure between variables, and this software is suitable for this model. 


\section{Findings}

The characteristics of the observed respondents are in terms of why companies using consultants in implementing ISO. A total of 157 respondents can provide more than one answer, but respondents' answers between one company with another are almost identical, as seen in Table 1.

Table 1. The Characteristics of Respondents Based on the Reasons in using Consultants

\begin{tabular}{|l|c|c|}
\hline Types of Project & Number & \% \\
\hline Faster in implementation & 34 & $10 \%$ \\
\hline Easier in implementation & 32 & $9 \%$ \\
\hline Better documentation & 54 & $16 \%$ \\
\hline Fewer numbers of employees & 32 & $9 \%$ \\
\hline More trusted by the management & 12 & $4 \%$ \\
\hline More independent and professional & 18 & $5 \%$ \\
\hline Recommended by the Board of Accreditation & 45 & $13 \%$ \\
\hline Certainty is getting the ISO certification & 65 & $19 \%$ \\
\hline More expert in implementation & 28 & $8 \%$ \\
\hline More control in implementation & 21 & $6 \%$ \\
\hline Total & 341 & $100 \%$ \\
\hline
\end{tabular}

From the characteristics of respondents who provide answers on the reasons for using consultants, the highest percentage is on company's certainty to obtain ISO certification with $19 \%$; the second percentage is the making of a better document by $16 \%$, and the third percentage is the recommendations by the certification board of $13 \%$. This shows that the companies concentrate on obtaining ISO certificates in order to innovate processes within the company and to make better documentation as required by ISO or the standard procedures.

The causal relationship developed in the hypothesis of this model needs to be tested by examining the null hypothesis, which states that the regression coefficient between the relations is not different from zero through the t-test as it is in the regression analysis. The statistical value of C.R will distribute the value of $t$ with degrees of freedom of 99 . The following is a description of the test results of the six main hypotheses proposed in the research. The use of the gamma symbol $(\gamma)$ shows the effect of exogenous constructs on endogens $(\mathrm{H} 1, \mathrm{H} 2$, and $\mathrm{H} 3)$, while the beta symbol $(\beta)$ shows the effect of endogenous constructs on endogens ( $\mathrm{H} 4, \mathrm{H} 5$, and H6). The following table summarizes the results of the six hypothesis testing.

Table 2. The Results of Research Hypothesis Testing

\begin{tabular}{|c|c|c|c|c|c|}
\hline Path Directions & $\begin{array}{c}\text { Regression } \\
\text { Coefficient }\end{array}$ & S.E. & C.R. & P & Sig 5 \% \\
\hline$(\mathrm{X} 1) \rightarrow(\mathrm{Y} 1)$ & $\gamma_{1}=0,682$ & 0,151 & 4,515 & 0,000 & 0,05 \\
\hline$(\mathrm{X} 2) \rightarrow(\mathrm{Y} 1)$ & $\gamma_{3}=0,352$ & 0,121 & 2,864 & 0,000 & 0,05 \\
\hline$(\mathrm{X} 2) \rightarrow(\mathrm{Y} 2)$ & $\gamma_{4}=0,295$ & 0,089 & 3,307 & 0,000 & 0,05 \\
\hline$(\mathrm{Y} 1) \rightarrow(\mathrm{Y} 2)$ & $\beta_{1}=0,584$ & 0,090 & 6,495 & 0,000 & 0,05 \\
\hline$(\mathrm{Y} 1) \rightarrow(\mathrm{Y} 3)$ & $\beta_{2}=0,415$ & 0,286 & 4,496 & 0,013 & 0,05 \\
\hline$(\mathrm{Y} 2) \rightarrow(\mathrm{Y} 3)$ & $\beta_{3}=0,723$ & 0,368 & 3,346 & 0,000 & 0,05 \\
\hline
\end{tabular}


Table 3. The Summary of the Research Hypothesis Results

\begin{tabular}{|l|l|c|l|}
\hline \multicolumn{1}{|c|}{$\begin{array}{c}\text { Initial Variable } \\
\text { Relationships }\end{array}$} & \multicolumn{1}{c|}{ With Final Variables } & $\begin{array}{c}\text { Intervening } \\
\text { Variable }\end{array}$ & \multicolumn{1}{c|}{ Result } \\
\hline $\begin{array}{l}\text { X1 (Consultant } \\
\text { Knowledge) }\end{array}$ & Y1 (learning Organization) & - & Significant \\
\cline { 2 - 4 } & Y2 (Best Practice) & Y1 & Significant \\
\cline { 2 - 4 } & Y3 (Enterprise Performance) & Y1 & Significant \\
\hline \multirow{3}{*}{$\begin{array}{l}\text { X3 (Operational Manager } \\
\text { Competence) }\end{array}$} & Y1 (learning Organization) & - & Significant \\
\cline { 2 - 5 } & Y2 (Best Practice) & - & Significant \\
\cline { 2 - 5 } $\begin{array}{l}\text { Y1 (learning } \\
\text { Organization) }\end{array}$ & Y2 (Enterprise Performance) & Y2 & Significant \\
\hline Y2 (Best Practice) & Y3 (Enterprise Performance) & - & Significant \\
\hline
\end{tabular}

The influence of the increasing knowledge of consultants toward the improvement of organizational learning is 0.682 and with significant $(\mathrm{P}=0.000)$. The results of this study support the research of Soe et al., [14], which states the activity and expertise of consultants participating in making effective and open communication bring impacts to the improvement of the learning process in the company and affect the company's performance.

The data analysis reveals that the path coefficient for the influence of the expertise and experience of operational managers to the improvement of organizational learning is 0.352 and with significant $(\mathrm{P}=0.000)$. The results of this study support the results of a research Soe et al., [14], which states that the skills of information technology managers positively affect the learning organization and information in South Korean companies in communicating among departments.

From the data analysis, the path coefficient for the influence of the operational managers' expertise and experience to the improvement of best practices is 0.295 with significant $(\mathrm{P}=0.000)$. The results of this study support the research by Soe et al. [14], which states the information technology manager's expertise positively affecting the sharing of knowledge and information within the South Korean companies in communicating among departments. From the analysis of the data, the path coefficient from the influence of the organizational learning to the improvement of best practices is 0.584 and with significant $(\mathrm{P}=0.000)$. That organizational learning gained from the knowledge sharing process between individual managers and outsourcing in the organization affects good product quality and reliable service and ultimately impacts the organization's performance.

The analysis of data reveals the path coefficient from the influence of improving organizational learning on the improvement of Corporate Performance as 0.415 with significant $(\mathrm{P}=0.000)$. The continuous sharing of knowledge and learning within the organization have an impact on the improvement of the operating business process, and ultimately on the improvement of the company's performance [17]. Based on the interviews with respondents, the managers often conduct coordination meetings in the morning before doing the field works, and every Monday the operation managers sit together to discuss the production processes and document the minutes well, so that other managers can read the results of the agreement. This brings an impact to the innovation in the company, and ultimately improves the performance of the company. From the data analysis, the path coefficient from the influence of improving best practices to the company performance is 0.723 with significant $(\mathrm{P}=0.000)$. Good business processes with standardized production and structured work processes have an impact on improving company performance [18]. 


\section{Conclusion}

Based on the results of data analysis and previous discussion, the research findings can be summarized as follows: Certain proficiency to receive knowledge from the consultants, so that top management has the ability to improve the organizational learning at manufacturing companies in the industrial area of MM-2100 Cikarang Bekasi, Indonesia. The increased skills and experiences of the competent operational managers can improve the organizational learning at manufacturing companies in the Industrial area MM-2100 Cikarang Bekasi. The company increased skills and experiences of the competent operational manager can produce the best business practices for the manufacturing companies in the Industrial Area MM-2100 Cikarang Bekasi. The intensively increased organizational learning is able to generate the best business practices for manufacturing and company performance financially for the manufacturing industries in the Industry Area of MM-2100 Cikarang Bekasi. The company enterprise improvement of the best business practices for the manufacturing industries in the Industrial Area MM-2100 Cikarang Bekasi is able to generate the company's performance.

\section{References}

1. A. Schokry, Introduction to Operations and Productions Management. [Presentation], Department of Industrial Engineering, Islamic University Gaza, Palestine (2011). http://site.iugaza.edu.ps/aschokry/files/2011/09/Introduction-toOperations-andProduction-management-chap-11.pdf

2. Y. Su, C. Yang, Expert Systems With Applications, 37:456-469(2010). https://linkinghub.elsevier.com/retrieve/pii/S0957417409004874

3. M.M. Costa, A.R.M. Lorente, T.Y. Choi, International Journal Production Economics 113:23-39(2008). https://www.sciencedirect.com/science/article/pii/S0925527307003088

4. J. Lee, S. Jang, S. Lee, Personnel Review, 47,5:1094-1115(2018). https://doi.org/10.1108/PR-03-2017-0068

5. A. Bilgihan, Y. Wang, Journal of Hospitality and Tourism Technology, 7,1:3759(2016). https://doi.org/10.1108/JHTT-01-2015-0001

6. M. El Mokadem, Journal of Manufacturing Technology Management, 27,3:338363(2016). https://doi.org/10.1108/JMTM-03-2015-0015

7. Z.J.H. Tarigan, W. Suprapto, S.R. Basana, The effect of procedure change, TQM and ERP implementation to company performance on manufacturing industries. IOP Conf. Series: Materials Science and Engineering 473, 012052, IOP Publishing (2019). https://iopscience.iop.org/article/10.1088/1757-899X/473/1/012052

8. J.L.S. Jones, K. Linderman, Business Process Management Journal, 20,2:335358(2014). https://doi.org/10.1108/BPMJ-03-2013-0026

9. A. Qureshi, N. Evans, Journal of Knowledge Management, 19,2:296-314(2015). https://doi.org/10.1108/JKM-09-2014-0391

10. W.B. Lin, Expert Systems with Applications 35:661-676(2008). https://www.sciencedirect.com/science/article/pii/S0957417407002783

11. A. Kianto, M. Vanhala, P. Heilmann, Journal of Knowledge Management, 20,4:621636(2016). https://doi.org/10.1108/JKM-10-2015-0398

12. H. Kasper, M. Lehrer, J. Mühlbacher, B. Müller, International Business Review, 22,1:326-338(2013). https://www.sciencedirect.com/science/article/pii/S0969593112000534 
13. D.I. Prajogo, A.S. Sohal, The International Journal of Management Science Omega 34:296-312(2006).

https://www.sciencedirect.com/science/article/pii/S0305048304001744

14. Y.W. Soe, H.S. Han, J.N. Lee, Research and Practice in Human Resources Management 13,2:1-15(2005).

https://www.sciencedirect.com/science/article/pii/S0305048304001744

15. S.Y. Sohn, H.S. Kim, T.H. Moon, Expert Systems with Applications 32:890-898 (2007). https://www.sciencedirect.com/science/article/pii/S0957417406000455

16. E. Naveh, A. Marcus, Accident Analysis and Prevention 39:731-742(2007). https://www.sciencedirect.com/science/article/pii/S0001457506002041

17. Z. Wang, N. Wang, Expert Systems with Applications, 39,10:8899-8908(2012), https://doi.org/10.1016/j.eswa.2012.02.017

18. A. Rondini, G. Pezzotta, S. Cavalieri, M.Z. Ouertani, F. Pirola, Computers in Industry 100:115-128(2018), https://doi.org/10.1016/j.compind.2018.04.010 